ISSN 0206-5657. Вісник Львівського університету. Серія біологічна. 2020. Випуск 83. С. 83-97 Visnyk of the Lviv University. Series Biology. 2020. Issue 83. P. 83-97

UDK: 612.13:612.01]-057.87 https://doi.org/10.30970/vlubs.2021.83.10

\title{
VEGETATIVE STATUS AND ADAPTATION PECULIARITIES POSSIBILITIES IN STUDENT YOUTH DEPENDING ON BLOOD CIRCULATION SELF-REGULATION TYPE
}

\author{
V. Zadorozhnia' ${ }^{1}$ O. Kuchkovsky ${ }^{2}$, O. Kovaleva ${ }^{3}$ \\ ${ }^{1}$ Zaporizhzhia National University \\ 66, Zhukovsky St., Zaporizhzhia 69600, Ukraine \\ ${ }^{2}$ Zaporizhzhia State Medical University \\ 26, Mayakovsky Ave., Zaporizhzhia 69000, Ukraine \\ ${ }^{3}$ State Institution "Zaporizhzhia Medical Academy of Post-Graduate Education \\ Ministry of Health of Ukraine", \\ 20, Vintera Blvd, Zaporizhzhia 69096, Ukraine \\ e-mail: zadorovic@gmail.com
}

Vegetative status and adaptive capabilities peculiarities of aged 19 to 21 girls depending on their blood circulation self-regulation type were studied in this work. The study was conducted at the Biology Faculty of Zaporizhzhia National University, Zaporizhzhia. Such primary indices as heart rate and blood pressure were studied in all test individuals. Based on the obtained data, the blood circulation self-regulation type in each subject was determined separately, which allowed to form three groups (individuals with cardiovascular, vascular and mixed blood circulation self-regulation types). The assessment scheme included cardiovascular system indices calculation such as average dynamic arterial pressure, specific peripheral resistance, cardiac output, cardiac index, stroke volume, external myocardial function, myocardial stress index, myocardial efficiency criterion, autonomic regulation index (vegetative Kerdo's index) and adaptive potential.

The results were processed by variation statistics methods, and the obtained data were subjected to correlation analysis.

Deviations from the reference values were revealed in systemic hemodynamics average group parameters analysis in female students with different blood circulation regulation types. It was recorded that the average dynamic pressure exceeded the normal upper limit by $2.5 \%$ and $6.2 \%$, respectively, in persons with mixed and vascular regulation type. Specific peripheral resistance indices obtained from data analysis in girls with different blood circulation self-regulation types revealed that this index did not exceed the normal in the groups with mixed and vascular type, in contrast to the group with the cardiac type. The specific peripheral resistance was lower by $5.2 \%$ than the lower limit of the reference value for this index in the latter group. Statistically significant differences were identified in cardiac output, cardiac index and stroke volume parameters in girls with different self-regulation circulatory types. Specific trends were identified in the average group and individual myocardial function indices in girls depending on the self-regulation type. Statistical significance was found between myocardial stress indices in girls with different self-regulation types. Both the average group and individual vegetative Kerdo's index indices fluctuated within eytony in the mixed type persons group. The mean group autonomic index values in girls with vascular type indicated pronounced vagotonia.

We found that the largest percentage of all respondents had satisfactory adaptation. The largest number of girls with satisfactory adaptation had a vascular self-regulation type $(83.33 \%)$ and a mixed type $(81.82 \%)$, a smaller percentage of girls from these groups ( $16.68 \%$ and $18.18 \%$, respectively) had adaptation mechanisms functional stress. In the

(C) Задорожня В., Кучковський О., Ковальова О., 2020 
group with the cardiac type, almost half (46.15\%) had adaptation mechanisms functional stress, and the rest (53.85\%) had satisfactory adaptation.

Thus, the differences in cardiovascular system indices, the autonomic nervous system sympathetic and parasympathetic parts influences ratio on the cardiovascular system were determined, as well as the adaptive potential in 19-21 years old girls can be attributed to blood circulation compensatory-adaptive reactions.

Keywords: adaptation, hemo- and cardiodynamics, autonomic regulation index, myocardial function indices, correlation

\section{Introduction}

It is generally accepted that a single neurohumoral system provides control of the adaptive process in the whole organism. The organism's ability to adapt to changing environmental conditions is determined by the reactivity of its vegetative department. The autonomic nervous system perceives, processes and transmits the received information to the executive organs in the form of control signals $[3,6]$. It is crucial in the regulation, coordination and adaptation of organs to the needs of the body $[30,31]$, which allows the body to adapt to new conditions and act as a whole $[33,39,41]$. Notably, vegetative tone and reactivity underline homeostatic capabilities, and the vegetative activity support can indicate the quality of adaptive mechanisms [25, 38].

The cardiovascular system is the most reactive system, being one of the first systems involved in the adaptation process to extreme conditions, and plays a leading role in maintaining body homeostasis [21, 29]. The modern scientific community is focusing its efforts on finding methods of comprehensive health assessment using one or more generalised integrating indices. An important cardiovascular system functional state index is a blood circulation self-regulation type (BCSRT) [20]. BCSRT determination makes it possible to assess the stress level in the cardiovascular system regulation [16].

Organism adaptive capacity assessment is particularly critical during the ontogenetic period, when biological maturation of the individual ends and all morphofunctional indices reach their definitive size [22]. During this period, physiological interactions between systems and organs are finally formed and systems relationships are established [13]. This period falls on the student age.

The aim of this work was to determine vegetative status and adaptive capabilities features of young females depending on their blood circulation self-regulation type.

This study is the second stage of cardiovascular system state assessing in students with different blood circulation self-regulation types. The results of the first study stage were published earlier [8].

\section{Materials and Methods}

The study was conducted at the Biology Faculty of Zaporizhzhia National University, Zaporizhzhia. The anonymous survey has been done by 56 "almost healthy" fourth-year students aged 19 to 21 (average age 20,37 $\pm 0,1$ years) and was conducted before classes in the morning. All girls had no history of chronic illness and no acute illnesses or other health complaints at the time of the examination.

Primary indices (heart rate (HR) and blood pressure (BP) were measured in a sitting position in all individuals. Based on the obtained data, the blood circulation self-regulation type (BCSRT) was determined for each subject separately. N.I. Arinchin's formula [4] was used to determine the BCSRT.

At the first study stage, all students were divided into 3 groups according to the blood circulation self-regulation type. At the second stage, the examination scheme included the cardio- 
vascular system indices calculation such as average dynamic arterial pressure (ADAP, mm $\mathrm{Hg}$ ) according to the Hickem formula, specific peripheral resistance (SPR, r.u.). Heart systolic function assessment was performed according to the cardiac output indices $(\mathrm{CO}, 1 / \mathrm{min})$, cardiac index $\left(\mathrm{CI}, 1 / \mathrm{min} \times \mathrm{m}^{2}\right)$ [36], stroke volume $(\mathrm{SV}, \mathrm{ml})$ according to Starr's formula [40]. The external myocardium work (EMW, r.u.) was evaluated according to the formula proposed by N.A. Agadzhanyan [21]. Myocardial stress index (MSI, r.u.) was calculated by the formula [1]. The myocardial efficiency criterion (MEC, r.u.) was determined by the formula [21].

The vegetative Kerdo's index (VKI, r.u.) was calculated to assess autonomic regulation mechanisms [11]. The adaptation potential (AP, r.u.) according to R.M. Baevsky [5] was used to assess the circulatory system functioning level.

The experiments results were processed by variation statistics methods with the software STATISTICA v.10.0 (StatSoft). The results reliability (significance) was assessed by the MannWhitney U-test (for parameters that do not obey the normal distribution law). The obtained data correlation analysis was performed. The minimum reliability was characterized by $\mathrm{p}<0,05$.

\section{Results and Discussion}

According to the BCSRT determining results in female students, it was found that the smallest number of people $(21,43 \%)$ had vascular BCSRT, $41,1 \%$ of girls had cardiac BCSRT, and $37,47 \%$ had mixed BCSRT.

Systemic hemodynamics mean group parameters analysis in female students with different BCSRT towards reference values revealed some deviations from the physiological norm (Table 1). In persons with mixed BCSRT and vascular BCSRT, it was recorded that ADAP exceeds the upper limit of normal by $2,5 \%$ and $6,2 \%$, respectively. In girls with cardiac BCSRT, the mean ADAP group values were within the upper limit of normal. Statistical analysis did not reveal statistically significant differences between groups on this index.

Average dynamic arterial pressure is one of the most stable indices. It is known that ADAP data is an index of consistency in the cardiac output and peripheral resistance regulation [27, 34] and characterizes the state of vascular tone and effective blood pressure [32,35]. The absence of statistically significant differences in the ADAP mean group values indicates relative stability of the energy expenditure, therefore it indicates regulatory homeostasis mechanisms strength [7] in girls with different BCSRT.

Table 1

Mean group female students hemo- and cardiodynamics indices depending on the blood circulation self-regulation type

Таблиця 1

Середньогрупові показники гемо- та кардіодинаміки студенток залежно від типу саморегуляції кровообігу

\begin{tabular}{|c|c|c|c|}
\hline $\begin{array}{ll}\text { Indices } & \text { Groups } \\
\end{array}$ & Cardiac BCSRT & Mixed BCSRT & Vascular BCSRT \\
\hline ADAP, $\mathrm{mm} \mathrm{Hg}$ & $84,62 \pm 2,57$ & $87,09 \pm 1,86$ & $90,28 \pm 1,94$ \\
\hline $\mathrm{CO}, 1 / \mathrm{min}$ & $5,01 \pm 0,08$ & $4,32 \pm 0,1 * * *$ & $3,32 \pm 0,29 * * *$ \#\# \\
\hline $\mathrm{CI}, 1 / \mathrm{min} \times \mathrm{m}^{2}$ & $3,02 \pm 0,12$ & $2,70 \pm 0,08^{*}$ & $2,10 \pm 0,17 * * * \# \#$ \\
\hline $\mathrm{SV}, \mathrm{ml}$ & $67,19 \pm 1,48$ & $64,26 \pm 2,32$ & $58,67 \pm 2,15^{* *}$ \\
\hline SPR, r.u. & $28,44 \pm 1,23$ & $32,62 \pm 1,29$ & $39,28 \pm 4,33$ \\
\hline
\end{tabular}

Notes: ${ }^{*}-\mathrm{p}<0,05 ; * *-p<0,01 ; * * *-p<0,001$ when compared between groups with mixed BCSRT or vascular BCSRT with cardiac BCSRT; \# $-\mathrm{p}<0,01$ when comparing groups with mixed BCSRT and vascular BCSRT 
$\mathrm{CO}, \mathrm{CI}$ and SV mean group indices analysis in girls with different BCSRT revealed statistically significant differences in these indices (Table 1) between groups. The highest $\mathrm{CO}$ rates were found in female students with cardiac BCSRT, which is by 33,7 \% $(\mathrm{p}<0,001)$ higher than in female students with vascular BCSRT and by $13,8 \%(\mathrm{p}<0,001)$ than in female students with mixed BCSRT. In the group of persons with vascular BCSRT, CO mean group values were lower by $30,1 \%(p<0,01)$ than in the group with mixed BCSRT. Thus, exceeding the CO norm upper limit was recorded for groups with cardiac BCSRT (by 43,1 \%) and mixed BCSRT (by 23,4 \%). In individuals with vascular BCSRT, the $\mathrm{CO}$ mean values in the group were within normal limits.

It is known that the $\mathrm{CO}$ reflects the cardiovascular system ability to sufficiently meet the body's need for oxygen [15].

According to the $\mathrm{CI}$ average group index calculation results, it was found that in persons with different BCSRT, the cardiac index fluctuates within normal limits. Some significant statistical differences in this index were observed between the three groups. The highest CI mean group index was determined in the group with cardiac BCSRT, which exceeded by $34,4 \%(p<0,001)$ the CI group with vascular BCSRT data and by $15,6 \%(\mathrm{p}<0,05)$ with mixed BCSRT. A statistically significant difference was also found between CI values in individuals with mixed BCSRT and vascular BCSRT. The CI index was statistically lower by $28,6 \%(\mathrm{p}<0,01)$ in representatives with vascular BCSRT compared with persons with mixed BCSRT.

The average SV group indices in representatives with cardiac and mixed BCSRT were within the normal limits, in contrast to persons with vascular BCSRT (Table 1). In girls with vascular BCSRT, the mean group SV was 3,8 \% below the lower reference values limit. Statistically significant differences in SV rate were found only between groups with cardiac and vascular BCSRT. SV was by $12,7 \%(\mathrm{p}<0,01)$ lower in girls with vascular BCSRT than with cardiac BCSRT.

The obtained SPR data analysis in girls with different BCSRT's has revealed that SPR does not exceed the norm in the groups of persons with mixed and vascular BCSRT, in contrast to the group with cardiac BCSRT. The last-named SPR was 5,2 \% lower than the lower reference value limit for this index.

Hemo- and cardiodynamics individual indices analysis has revealed certain features in three groups individuals. The highest percentage of people with ADAP within the norm was determined in the group with mixed BCSRT (Fig. 1-3), and the lowest percentage - in the group with vascular BCSRT. Individuals $(83,33 \%)$ with ADAP rates above the norm were predominant in the group of girls with vascular BCSRT, which is by $28,8 \%$ higher than in the group of girls with mixed BCSRT and 37,2 \% higher than in those with cardiac BCSRT. An increase in ADAP indicates an increase in vascular tone and a certain trend in the imbalance of cardiac output and peripheral resistance [26]. A small percentage (23,08\%) of people with ADAP below the reference values was found in the group of girls with cardiac BCSRT.

In the group with vascular BCSRT, the CO normal values excess $(3,86 \pm 0,141 / \mathrm{min})$ was observed in the half of girls, a smaller proportion (33,3\%) of girls had $\mathrm{CO}$ within normal limits $(3,11 \pm 0,031 / \mathrm{min})$, and in $16,6 \%$ of individuals $\mathrm{CO}$ values were lower $(2,12 \pm 0,01 \mathrm{l} / \mathrm{min})$ than reference values.

$\mathrm{CO}$ individual values distribution analysis showed normative data excess in all respondents with cardiac and mixed BCSRT (Fig. 1-3). CO characterizes both inotropic and chronotropic heart function [17]. CO indices evaluation provides information about cardiovascular system functional reserve [18]. It is known that a CO increase indicates an increase in body metabolic reactions intensity, and a CO decrease is an efficiency and myocardial weakness index [14]. It is believed that the cardiac output is more accurately expressed by the cardiac index value. The 
cardiac index value is considered to be one of the most informative parameters that characterizes the left ventricle functional state [17], therefore it is a heart pumping function index.

CI assessment in the groups of girls with cardiac and mixed BCSRT has revealed that all individuals had CI values within the reference values (Fig. 1-3). The vast majority $(66,67 \%)$ among girls with vascular BCSRT (Fig. 3) had CI values within the normal limits $(2,25 \pm 0,11 \mathrm{l} /$ $\left.\min \times \mathrm{m}^{2}\right)$. The cardiac index is lower by $32 \%$ of the normal lower limit $\left(1,36 \pm 0,01 \mathrm{l} / \mathrm{min} \times \mathrm{m}^{2}\right)$, and it was determined in a lower percentage of people $(16,67 \%)$ in this group. Decreased CI can be seen as a certain weakening of the heart's ability to pump blood.

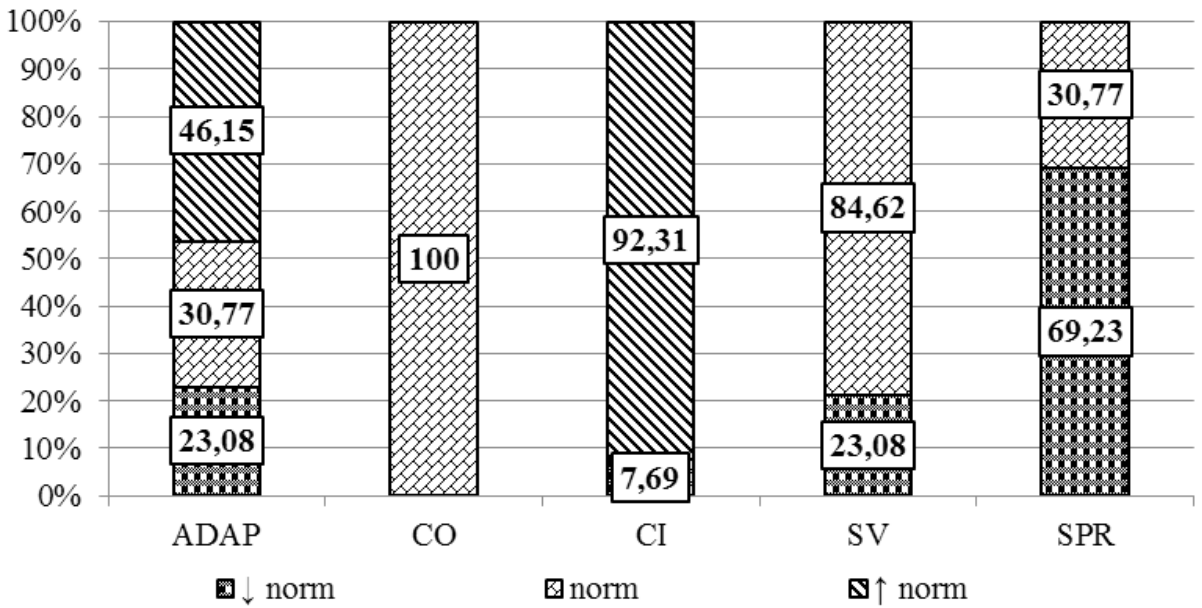

Fig. 1. Hemo- and cardiodynamics individual indices distribution in female students with cardiac blood circulation self-regulation type

Рис. 1. Розподіл індивідуальних показників гемо- та кардіодинаміки студенток зі серцевим типом саморегуляції кровообігу

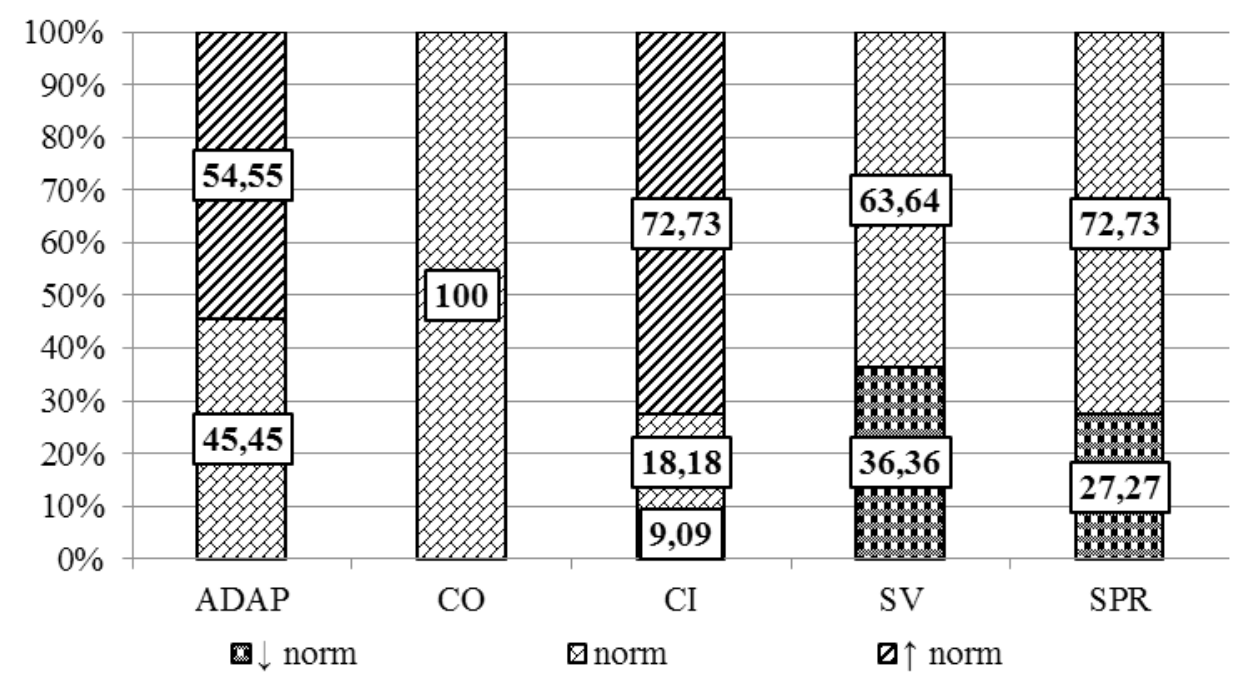

Fig. 2. Hemo- and cardiodynamics individual indices distribution in students with mixed blood circulation self-regulation type

Рис. 2. Розподіл індивідуальних показників гемо- та кардіодинаміки студенток зі змішаним типом саморегуляції кровообігу 


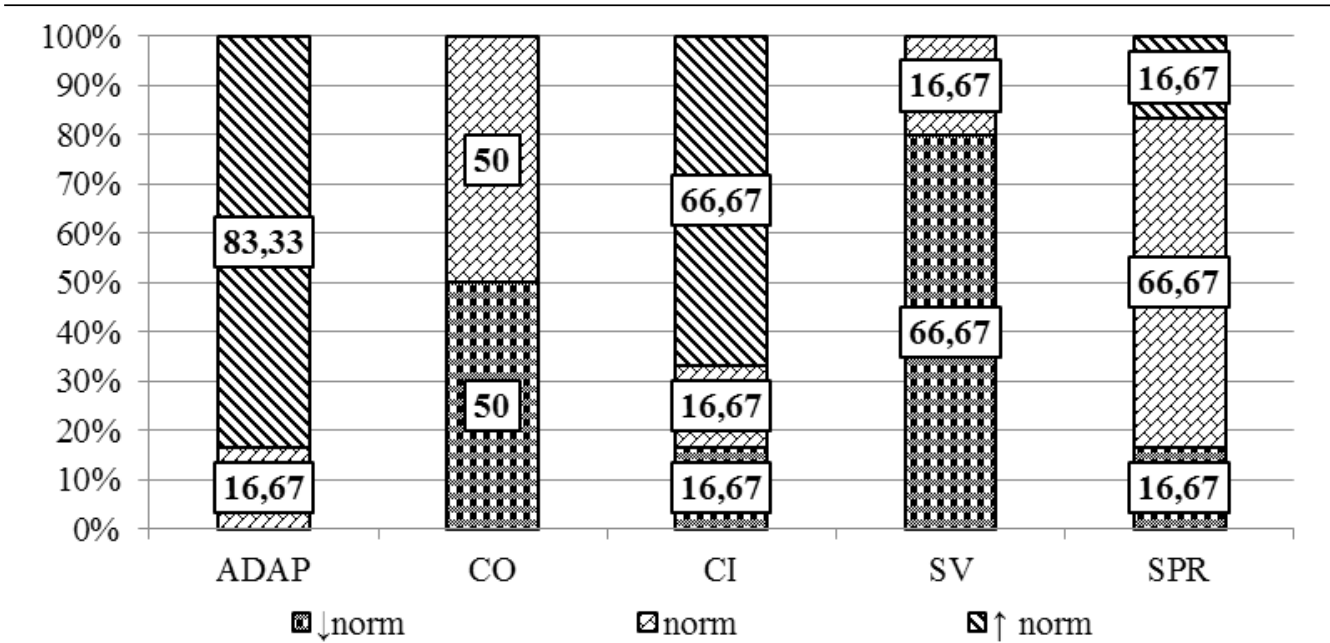

Fig. 3. Hemo- and cardiodynamics individual indices distribution in students with vascular blood circulation self-regulation type

Рис. 3. Розподіл індивідуальних показників гемо- та кардіодинаміки студенток зі судинним типом саморегуляції кровообігу

SV individual indices analysis has revealed certain persons with different types of BCSRT percentage distribution features in relation to the norm indices (Fig. 1-3). The highest percentage of girls with SV reference values was determined in the groups with cardiac and mixed BCSRT: $84,62 \%-68,43 \pm 1,46 \mathrm{ml}$ and $63,64 \%-69,21 \pm 1,27 \mathrm{ml}$.

A small percentage of individuals $(16,68 \%)$ with normal SV $(67,0 \pm 0,01 \mathrm{ml})$ was detected in the group with vascular BCSRT. No girls with high SV were found in the three examined groups. The highest percentage of people $(66,67 \%)$ with low SV $(57,0 \pm 1,17 \mathrm{ml})$ belonged to the group with vascular BCSRT. Slight reductions in SV were found in girls with cardiac $(60,4 \pm 0,01$ $\mathrm{ml})$ and mixed $(55,6 \pm 2,15 \mathrm{ml}) \mathrm{BCSRT}-23,08 \%$ and $36,36 \%$ respectively. It is known that a SV decrease on the background of high $\mathrm{CO}$ may be an adaptive response to cardiac hypoxia, which is a concomitant negative factor in the educational process [10], which is directly associated with hypodynamia and high mental strain.

SPR individual indices distribution evaluation has shown that the vast majority of girls (Fig. 1-3) with mixed and vascular BCSRT had SPR reference data $-34,06 \pm 1,48$ and $37,69 \pm 0,33$ r.u. respectively. The smallest part of girls with mixed and vascular BCSRT had low SPR: $27,27 \%-28,77 \pm 0,27$ and $16,67 \%-26,16 \pm 0,01$ r.u. respectively.

A small percentage of girls $(16,67 \%)$ in the group of persons with vascular BCSRT had above-normal SPR rates $(58,73 \pm 0,01$ r.u.). Elevated SPR was not detected among girls with mixed BCSRT.

The predominant number $(69,23 \%)$ in girls with cardiac BCSRT (Fig. 1) had a low SPR rate $-25,96 \pm 0,86$ r.u., and in other persons $(30,77 \%)$ this index was within the norm $-33,99 \pm 0,7$ r.u.

It is known that SPR determines the average dynamic pressure constancy and its deviation from the norm indicates obstacles in the blood passage through the vascular bed [34]. Thus, reduced and reference SPR indices of girls with cardiac and mixed BCSRT indicate adequacy and appropriateness of compensatory mechanisms, and persons with elevated SPR (from the group with vascular BCSRT) are at cardiovascular risk, and this may lead to further cardiovascular remodelling [9]. 
Therefore, determined changes in hemodynamic parameters may also be a consequence of age-related changes, because it is known that student age is characterized by the completion of biological maturation $[2,12]$.

Myocardial function average group and individual indices statistical analysis has revealed specific trends in girls depending on the BCSRT (Table 2). It is known that the MSI is a relative value that shows what part of the cardiomyocyte stress time is spent preparing to expel blood from the heart [1], ie the MSI proves what part of the ventricular contraction time is spent unproductively, while the ventricle does not do external work [19]. The statistically significant differences in the MSI data may be due to the instability of female students cardiovascular system adaptive responses [7].

Statistically significant differences were found between MSI indices in girls with different BCSRT. The highest MSI rate was in persons with cardiac BCSRT, which is by $8,81 \%(\mathrm{p}<0,05)$ more than in girls with mixed BCSRT and by $23,67 \%(\mathrm{p}<0,05)$ compared with the group with vascular BCSRT.

Despite the fact that the average MSI group indices in girls with different BCSRT were within the norm (6,6-9,6 r.u.), individual data analysis has revealed certain features for each group. Individuals with normal and elevated MSI were found among the girls with cardiac BCSRT, and their percentage was distributed almost evenly (Table 2). However, individuals with MSI reference values were predominating in the group of girls with mixed BCSRT, and only a small proportion had increased MSI. Another picture was observed in the group of girls with vascular BCSRT: the largest percentage of girls had MSI reference values, but also people with low MSI were detected. No statistically significant differences were found (Table 2) according to the EMW and MEC average group indices analysis results. EMW average group indices in the three groups fluctuated within the norm (4,5-6,5 r.u.). Differences were established at EMW individual analysis in girls with various BSCSRT. Specific percentage distribution based on individual data on norm indices has been determined. There were no individuals with EMW values above and below the norm among the girls with cardiac BCSRT, and all girls in this group had EMW values within the norm (Table 2).

Table 2

Myocardial function average group and individual indices in fourth-year students depending on the blood circulation self-regulation type

Таблиця 2

Середньогрупові та індивідуальні показники роботи міокарда студенток IV курсу залежно від типу саморегуляції кровообігу.

\begin{tabular}{|c|c|c|c|c|c|c|c|c|c|c|}
\hline \multirow{2}{*}{\multicolumn{2}{|c|}{ Indices }} & \multicolumn{3}{|c|}{ Cardiac BCSRT } & \multicolumn{3}{|c|}{ Mixed BCSRT } & \multicolumn{3}{|c|}{ Vascular BCSRT } \\
\hline & & \multirow{2}{*}{$\begin{array}{c}\% \\
46,15 \\
\end{array}$} & \multicolumn{2}{|c|}{$\overline{\mathrm{X}} \pm S_{\mathrm{x}}$} & \multirow{2}{*}{$\begin{array}{c}\% \\
18,18 \\
\end{array}$} & \multicolumn{2}{|c|}{$\overline{\mathrm{X}} \pm S_{\mathrm{x}}$} & \multirow{2}{*}{$\begin{array}{l}\% \\
- \\
\end{array}$} & \multicolumn{2}{|c|}{$\overline{\mathrm{X}} \pm S_{\mathrm{x}}$} \\
\hline \multirow{3}{*}{$\begin{array}{l}\text { MSI, } \\
\text { r.u. }\end{array}$} & $\uparrow N$ & & $11,09 \pm 0,18$ & \multirow{3}{*}{$9,42 \pm 0,49$} & & $10,12 \pm 0,44$ & & & - & \multirow{3}{*}{$7,19 \pm 0,58$} \\
\hline & $\mathrm{N}$ & 53,85 & $7,98 \pm 0,39$ & & 81,82 & $8,25 \pm 0,31$ & & 83,33 & $7,68 \pm 0,37$ & \\
\hline & $\downarrow N$ & - & - & & - & - & - & 16,67 & $4,74 \pm 0,01$ & \\
\hline \multirow{3}{*}{$\begin{array}{l}\text { EMW, } \\
\text { r.u. }\end{array}$} & $\uparrow \mathrm{N}$ & - & - & - & 9,09 & $6,54 \pm 0,01$ & \multirow{2}{*}{$5,57 \pm 0,15$} & - & - & \multirow{3}{*}{$5,29 \pm 0,2$} \\
\hline & $\mathrm{N}$ & 100 & \multicolumn{2}{|c|}{$5,65 \pm 0,13$} & 90,91 & $5,47 \pm 0,13$ & & 83,33 & $5,47 \pm 0,12$ & \\
\hline & $\downarrow N$ & - & - & - & - & - & - & 16,67 & $4,42 \pm 0,01$ & \\
\hline \multirow{3}{*}{$\begin{array}{c}\text { MEC, } \\
\text { r.u. }\end{array}$} & $\uparrow N$ & 23,08 & $0,81 \pm 0,01$ & \multirow{3}{*}{$0,62 \pm 0,03$} & 63,64 & $0,73 \pm 0,02$ & \multirow{3}{*}{$0,66 \pm 0,03$} & 50 & $0,87 \pm 0,1$ & \multirow{3}{*}{$0,76 \pm 0,07$} \\
\hline & $\mathrm{N}$ & - & - & & - & - & & 16,67 & $0,67 \pm 0,01$ & \\
\hline & $\downarrow N$ & 84,62 & $0,58 \pm 0,02$ & & 36,36 & $0,53 \pm 0,02$ & & 33,33 & $0,64 \pm 0,01$ & \\
\hline
\end{tabular}

Notes: $\uparrow \mathrm{N}$ - above normal; $\mathrm{N}$ - norm; $\downarrow \mathrm{N}$ - below normal 
The vast majority of girls with mixed BCSRT also had a normal EMW, but we have also found a small percentage of people with very high EMW. The majority had EMW indices within the reference values in the group of girls with vascular BCSRT, and a small proportion had these indices below the normal (Table 2).

The mean group MEC indices had some differences in relation to the norm $(0,66-0,68$ r.u.) in girls with different BCSRT. This index was below the lower normal limit by $7,46 \%$ in girls with cardiac BCSRT, and it was above the upper normal limit by $11,76 \%$ in the group with vascular BCSRT. MEC indices were within the norm in persons with mixed BCSRT.

It is known that large MEC values, as well as a decrease in MEC value, which is characteristic for girls with vascular BCSRT, may indicate that cardiovascular system adaptive responses are relatively high level [15].

Individual MEC indices analysis revealed an opposite percentage of individuals in relation to the norm in girls with cardiac and mixed BCSRT: the highest percentage of girls with cardiac BCSRT had MEC below normal, and the largest number of girls with mixed BCSRT had it above normal. No girls with reference MEC values were detected in both groups. Half of the girls with vascular BCSRT had high MEC, a third of them had low MEC, and only a small percentage $(16,67 \%)$ had MEC within normal limits.

Thus, during the cardiovascular performance dynamics study in female students during five years of higher education, the authors [19] have determined that low MEC coincides with the myocardial contractility deterioration in this period.

The decisive role belongs to the autonomic nervous system (ANS) in the regulation, coordination and adaptation of the organs depending on the needs of the body [30, 31]. ANS plays an important integrative role at the central level, allowing the body to adapt to new conditions and resume its work as a whole $[33,39,41]$.

Vegetative Kerdo's index (VKI) analysis shows sympathetic and parasympathetic nervous systems influence ratio on the cardiovascular system and reveals some clear differences between the three groups of girls with different BCSRT (Fig. 4).

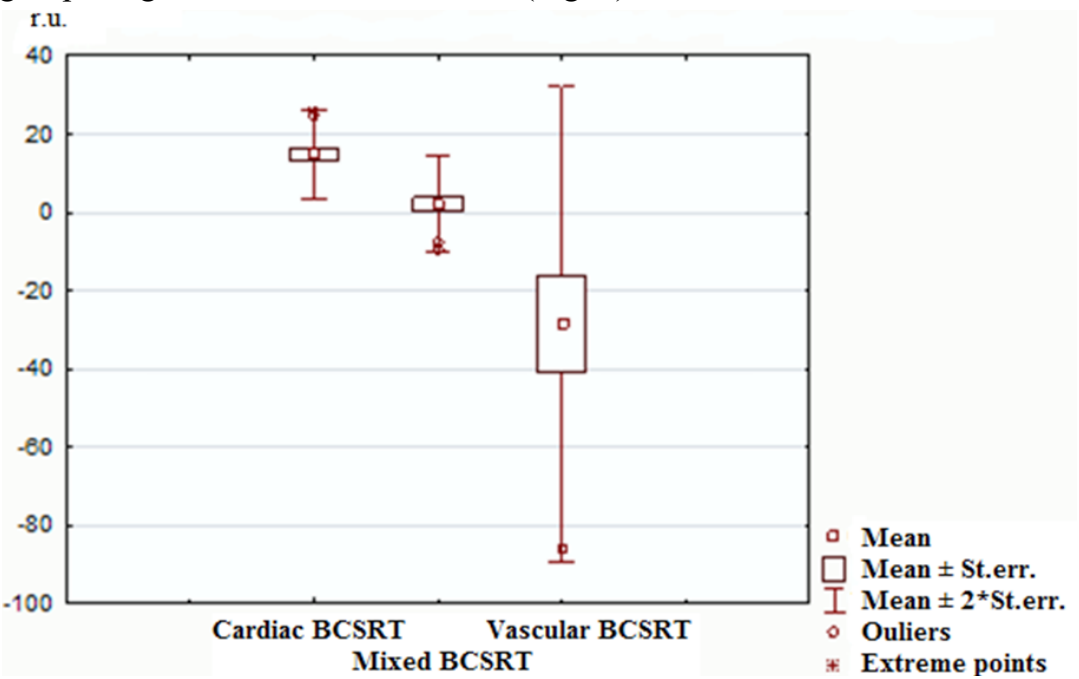

Fig. 4. Vegetative Kerdo's index average group indices scope in fourth-year students depending on blood circulation self-regulation type

Рис. 4. Розмах середньогрупових показників вегетативного індексу Кердо у студенток IV курсу залежно від типу саморегуляції кровообігу 
The mean group VKI was close to the eytony upper limit in girls with cardiac BCSRT, and the majority of female students $(53,85 \%)$ had a relative balance between the sympathetic and parasympathetic systems, while the remaining (46,15\%) girls has shown sympathicotonia. Both the mean group and individual VKI indices ranged within the eytony in the group of people with mixed BCSRT. The majority of girls $(66,67 \%)$ with vascular BCSRT had VKI values approaching the lower eytony limit, and the remaining girls $(33,33 \%)$ had a pronounced vagotonia. Mean group VKI values indicated pronounced vagotonia in girls with vascular BCSRT.

It is proved that the autonomic nervous system parasympathetic part regulates physiological processes that ensure homeostasis [23]. The parasympathetic part performs the task of internal environment stability restoration and maintenance after any violations and shifts [37]. The sympathetic part is "protective", a reserve mobilization system, which is necessary for the organism's active action, and such mobilization requires many structures and organs mobilisation [23]. The sympathetic nervous system performs an adaptive-trophic function and excitability of all organs and tissues to meet metabolic needs of the body. When the body is mobilized and the sympathetic nervous system is activated, key parameters of homeostasis also change [23, 28].

It was found in correlations analysis (Table 3) that girls with different BCSRT have a strong direct relationship $(0,77<\mathrm{r}<0,90)$ between $\mathrm{CO}-\mathrm{CI}$, strong feedback $(-0,7<\mathrm{r}<-0,99)$ between CI-SPR, MEC-MSI and SPR-VKI. A strong direct relationship $(0,91<\mathrm{r}<0,96)$ was found between ADAP-MSI and SV-MEC in groups of individuals with cardiac BCSRT and mixed BCSRT, and a strong feedback $(-0,68<\mathrm{r}<-0,78)$ was found between ADAP-SV, ADP-MEC and SV-MSI indices.

Table 3

Correlation coefficients between hemodynamic parameters in girls 19-21 years old

Таблиця 3

Коефіцієнти кореляції між гемодинамічними показниками у дівчат 19-21 років

\begin{tabular}{|c|c|c|c|}
\hline Indices & Cardiac BCSRT & Mixed BCSRT & Vascular BCSRT \\
\hline ADAP-CO & 0,60 & $-0,27$ & $-0,07$ \\
\hline ADAP-SV & $-0,68$ & $-0,72$ & $-0,17$ \\
\hline ADAP-MEC & $-0,78$ & $-0,78$ & $-0,07$ \\
\hline ADAP-EMW & 0,70 & $-0,25$ & 0,43 \\
\hline ADAP-MSI & 0,96 & 0,91 & 0,33 \\
\hline $\mathrm{CO}-\mathrm{CI}$ & 0,83 & 0,77 & 0,95 \\
\hline $\mathrm{CO}-\mathrm{SV}$ & $-0,43$ & 0,62 & 0,62 \\
\hline CO-MEC & $-0,68$ & 0,24 & $-0,76$ \\
\hline CO-EMW & 0,43 & 0,67 & 0,52 \\
\hline CO-MSI & 0,75 & 0,01 & 0,88 \\
\hline CO-SPR & $-0,33$ & $-0,79$ & $-0,93$ \\
\hline $\mathrm{CO}-\mathrm{VKI}$ & 0,21 & 0,57 & 0,92 \\
\hline CI-SPR & $-0,72$ & $-0,82$ & $-0,99$ \\
\hline CI-VKI & 0,39 & 0,78 & 0,93 \\
\hline SV-MEC & 0,95 & 0,91 & 0,02 \\
\hline SV-EMW & 0,05 & 0,85 & 0,82 \\
\hline SV-MSI & $-0,77$ & $-0,71$ & 0,29 \\
\hline MEC-EMW & $-0,16$ & 0,67 & $-0,02$ \\
\hline MEC-MSI & $-0,90$ & $-0,90$ & $-0,89$ \\
\hline MEC-VKI & $-0,12$ & $-0,35$ & $-0,92$ \\
\hline EMW-MSI & 0,56 & $-0,29$ & 0,46 \\
\hline EMW-VKI & $-0,77$ & $-0,22$ & 0,17 \\
\hline MSI-VKI & $-0,24$ & 0,24 & 0,85 \\
\hline SPR-VKI & $-0,70$ & $-0,78$ & $-0,94$ \\
\hline
\end{tabular}

Notes: The correlation coefficient is specified. Values in bold italics are statistically significant $(\mathrm{p}<0,05)$ 
A strong direct relationship $(0,75<\mathrm{r}<0,93)$ was shown between CO-MSI, CI-VKI and SV-EMW in girls with cardiac and vascular BCSRT, and strong feedback seen only between CO-SPR. In addition, girls with cardiac BCSRT were found to have correlations between the indices, according to which people with other types of BCSRT had no correlations. Namely, moderate direct connection $(0,56<\mathrm{r}<0,70)$ was between ADAP-CO, ADAP-EMW and EMW-MSI, and feedback between CO-MEC and EMW-VKI.

A moderate direct connection $(0,62<\mathrm{r}<0,67)$ was detected in only three pairs of indices (CO-SV, CO-EMW and MEC-EMW) in girls with altered BCSRT, and no statistically significant correlations were found between these indices in girls with other BCSRT.

There was a strong direct relationship $(0,85<\mathrm{r}<0,92)$ between $\mathrm{CO}-\mathrm{VKI}$ and MSI-VKI and a strong feedback relationship between MEC-VKI in subjects with vascular BCSRT. No statistically significant correlations were found between these indices in girls with other BCSRT.

Therefore, the corresponding blood pressure level in cardiac BCSRT is maintained mainly by $\mathrm{CO}$, as evidenced by a moderate direct relationship between $\mathrm{ADAP}-\mathrm{CO}$, in contrast to other BCSRT, in which the correlations between these indices were absent. At vascular BCSRT the optimum blood pressure level is supported at the expense of SPR.

In order to identify circulatory system compensatory-adaptive mechanisms, we performed circulatory system adaptive potential (AP) calculations. The distribution of girls based on AP found that the vast majority of all respondents had a satisfactory adaptation. The largest percentage of girls with satisfactory adaptation had vascular BCSRT $(83,33 \%)$ and mixed BCSRT $(81,82 \%)$, and a smaller percentage of girls from these groups $(16,68 \%$ and $18,18 \%$, respectively) had adaptation mechanisms functional stress. Almost half $(46,15 \%)$ had adaptation mechanisms functional stress in the group with cardiac BCSRT, and the rest $(53,85 \%)$ had satisfactory adaptation.

Thus, the differences in cardiovascular system indices, the ANS sympathetic and parasympathetic parts influence ratio on the cardiovascular system, as well as in the adaptive potential in 19-21 years old girls can be attributed to compensatory-adaptive reactions caused by different circulatory self-regulation types.

\section{REFERENCES}

1. Агаджанян Н.А., Ермакова Н.В. Экологический портрет человека на Севере. М.: КРУК, 1997. $208 \mathrm{c}$.

Agadzhanyan N.A., Ermakova N.V. Ecological portrait of a man in the North. Moscow: KRUK, 1997. 208 p. (In Russian)

2. Агаджанян Н.А., Руженкова И.В., Старшинов Ю.П. и др. Особенности адаптации сердечно-сосудистой системы юношеского организма // Физиология человека. 1997. T. 23. № 1. C. 93-97.

Agadzhanyan N.A., Ruzhenkova I.V., Starshinov Yu.P., et al. Features of the Adaptation of the Cardiovascular System of the Juvenile Body // Fiziol. Chel. 1997. Vol. 23. № 1. P. 93-97. (In Russian)

3. Агафонкина Т.В., Кострова О.Ю. Показатели вегетативной нервной системы и академическая успеваемость студентов // Вестн. Чувашск. ун-та. 2008. № 2. С. 42-45. Agafonkina T.V., Kostrova O.U. Parameters of a Vegetative Nervous System and the Academic Progress of Students // Bulletin Chuvashsk. Univer. 2008. № 2. P. 42-45. (In Russian)

4. Аринчин Н.И. Комплексное изучение сердечно-сосудистой системы. Минск: Наука и техника, 1961. 220 с. 
Arinchin N.I. Complex study of the cardiovascular system. Minsk: Science and Technology, 1961. 220 p. (In Russian)

5. Баевский Р.М., Берсенева А.П., Вакулин В.К. Оценка эффективности профилактических мероприятий на основе измерения адаптационного потенциала системы кровообращения // Здравоохранение Российской Федерации. 1987. № 9. С. 5-23.

Baevsky R.M, Berseneva A.P, Vakulin V.K. Evaluation of the effectiveness of preventive measures based on measuring the adaptive potential of the circulatory system // Zdravookhranenie Rossijskoj Federacii. 1987. № 9. P. 5-23. (In Russian)

6. Вейн А.М. Вегетативные расстройства: клиника, диагностика, лечение / под ред. А.М. Вейна. М.: ООО «Мед. информ. агентство», 2003. 752 с.

Wayne A.M. Vegetative disorders: clinical picture, diagnosis, treatment / ed. A.M. Wayne. Moscow: LLC «Medical Information Agency», 2003. 752 p.

7. Ермолин С.П. Физиологические реакции организма военнослужащих в условиях Арктической зоны Российской Федерации: автореф. дис. ... канд. мед. наук 03.03.01 / Северный гос. мед. ун-т. Архангельск, 2015. 139 с.

Ermolin S.P. Physiological reactions of the body of military personnel in the Arctic zone of the Russian Federation. dis .... cand. medical. sciences 03.03.01 / Northern State Medical University. Arkhangelsk, 2015.139 p. (In Russian)

8. Задорожня В.Ю., Гавриленко О.Ю. Особливості реакції серцево-судинної системи студентів із різним типом саморегуляції кровообігу // Вісн. Запор. ун-ту. Сер. Біол. науки. 2017. № 2. C. 56-66.

Zadorozhnja V.Yu., Gavrilenko O.Yu. Cardiovascular system reaction features of students with different type of blood circulation autoregulation // Bulletin of Zaporizhzhia National University. Biological Sciences. 2017. №. 2. P. 56-66. (In Ukrainian)

9. Клименко T.M., Яйленко А.A. Начальные признаки сердечно-сосудистого ремоделирования у подростков с артериальной гипертензией // Совр. проблемы науки и образования. 2014. № 6. URL: http://www.science-education.ru/ru/article/view?id=16999. Klimenko T.M., Yailenko A.A. Initial signs of cardiovascular remodeling in adolescents with hypertension // Modern Problems of Science and Education. 2014. № 6. (In Russian). URL: http://www.science-education.ru/ru/article/view?id=16999

10. Коновалова Г.М., Севрюкова Г.А. Физиологические аспекты адаптации студенческой молодежи // Вестн. СГУТиКД. 2011. № 2 (16). С. 144-155.

Konovalova G.M., Sevryukova G.A. Physiologial aspects of students` adaptation // Bulletin of SGUTiKD. 2011. № 2 (16). P. 144-155. (In Russian)

11. Кучкин С.Н., Ченегин В.М. Методы исследования в возрастной физиологии физических упражнений и спорте: уч. пособ. Волгоград: ВГАФК, 1998. 87 с.

Kuchkin S.N., Chenegin V.M. Research methods in age-related physiology of physical exercise and sports: a tutorial. Volgograd: VGAFK, 1998. 87 p. (In Russian)

12. Левушкин С.П. Комплексная оценка физической работоспособности юношей // Физиология человека. 2001. Т. 27. № 5. С. 68-75.

Levushkin S.P. Comprehensive assessment of the physical performance of young men // Human Physiology. 2001. Vol. 27. № 5. P. 68-75. (In Russian)

13. Лисова И.М. Адаптационные возможности и конституциональные особенности организма студентов разных климатогеографических регионов: автореф. дис. ... канд. биол. наук. Ставрополь, 2002. 22 с. 
Lisova I.M. Adaptive capabilities and constitutional characteristics of the organism of students in different climatic and geographical regions: author. ... diss. cand. biol. sciences. Stavropol, 2002. 22 p. (In Russian)

14. Лутай М.И. Частота сокращений сердца и сердечная недостаточность. Взгляд клинициста // Укр. кардіол. журнал. 2011. № 2. С. 7-14.

Lutai M.I. Heart rate and heart failure. A view of the clinician // Ukrainian Association of Cardiology. 2011. № 2. P. 7-14. (In Russian)

15. Мануйлов И.В. Физиологическая характеристика адаптивных реакций кардиореспираторной системы у лыжников массовых спортивных разрядов в годовом цикле на европейском севере: дис. ... канд. мед. наук, 03.03.01 / Северный гос. мед. унт. Архангельск, 2014. 142 с.

Manuilov I. V. Physiological characteristics of adaptive reactions of the cardiorespiratory system in skiers of mass porous discharges in the annual cycle in the European north: dis. ... cand. medical. sciences, 03.03.01 / Northern State Medical University. Arkhangelsk, 2014. 142 p. (In Russian)

16. Мельник C.Н., Мельник B.B. Особенности показателей сердечно-сосудистой системы студентов с различными типами саморегуляции кровообращения // Проблемы здоровья и экологии. 2019. № 2(60). С. 80-85. URL: http://elib.gsmu.by/handle/GomSMU/5541

Melnik S.N., Melnik V.V. The Features of the Indices of Cardiovascular System of Students with Different Types of Self-Regulation of Blood Circulation // Problemy zdorovya i ekologii. 2019. Vol. 60(2). P. 80-85. (In Russian). URL: http://elib.gsmu.by/handle/GomSMU/5541

17. Михайлов B.M. Вариабельность ритма сердца: опыт практического применения метода. Иваново: Ивановская мед. академия, 2002. 290 с.

Mikhailov V.M. Heart rate variability: experience of practical application of the method. Ivanovo: Ivanovo Med. Academy, 2002. 290 p. (In Russian)

18. Нагорнов И.В., Хоровеи С., Фролов А.Ю., Лазаренко В.П. Предупреждение развития утомления у студентов с разной физической активностью // Вестн. ЮУрГУ. 2008. № 14. C. $108-110$.

Nagornov I.V., Horovets S., Frolov A.Yu., Lazarenko V.P. Prevention of the development of fatigue in students with different physical activity // Bulletin of YuUrGU. 2008. № 14. P. 108-110. (In Russian)

19. Палкина О.А., Гудков А.Б., Шаренкова Л.А. Динамика показателей деятельности сердечно-сосудистой системы студенток в течение пятилетнего обучения в ВУЗе // Экология человека. 2007. Т. 2. С. 22-25.

Palkina O.A., Gudkov A.B., Sharenkova L.A. Dynamics of indices of cardio-vascular system activity in girls-students during 5-year studies at higher educational institution // Human Ecology. 2007. Vol. 2. P. 22-25. (In Russian)

20. Петров C.B. Особенности механизмов формирования типов саморегуляции кровообращения: автореф. дис. ... канд. мед. наук 14.00.17 / Московская мед. академия им. И.М. Сеченова; НИИ нормальной физиологии им. П.К. Анохина РАМН. М., 1996. $20 \mathrm{c}$.

Petrov S.V. Peculiarities of mechanisms of formation of types of blood circulation autoregulation: author. dis. ... cand. med. sciences 14.00.17 / Moscow med. academy named after I. M. Sechenov; Scientific Research Institute of Normal Physiology. PC. Anokhin RAMS. Moscow, 1996. 20 p. (In Russian) 
21. Пирогова Е.А., Иващченко Л.Я., Страпко Н.П. Влияние физических упражнений на работоспособность человека. К.: Здоровье, 1986. 152 с.

Pirogova E.A., Ivaschenko L.Ya., Strapko N.P. The influence of physical exercise on human performance. K.: Health, 1986.152 p. (In Russian)

22. Филатов О.М., Щедрина А.Г. Роль индивидуальной изменчивости организма в формировании здоровья студентов // Гигиена и санитария. 1996. Т. 6. С. 29-32.

Filatov O.M., Shchedrina A.G. The role of individual variability of the organism in the formation of students' health // Hygiene and sanitation. 1996. T. 6. P. 29-32. (In Russian)

23. Шебеко Л.Л., Апанович А.П., Ткачук Л.В. и др. Оценка вегетативной регуляции как средство контроля эффективности занятий физической культурой и спортом у студентов факультета организации здорового образа жизни на протяжении 4 лет обучения в университете // Здоровье для всех. 2015. № 1. С. 3-10.

Shebeko L.L., Apanovich A.P., Tkachuk L.V. and al. Assessment of autonomic regulation as a means of monitoring the effectiveness of physical culture exercises and sports among students of healthy way of life organization faculty for 4 years study at the university // Health for all. 2015. №. 1. P. 3-10. (In Russian)

24. Braune S., Auer A. Cardiovascular parameters; sensitivity to detect autonomic dysfunction and influence of age and sex in normal subjects // Clin. Auton. Res. 1996. Vol. 6. 1. P. 3-15.

25. Bustamante-Sanchez A., Tornero-Aguilera J.F., V.E. Fernandez-Elıas and al. Effect of Stress on Autonomic and Cardiovascular Systems in Military Population: A Systematic Review // Cardiology Research and Practice 2020. Article ID 7986249 URL: https://www.hindawi. com/journals/crp/2020/7986249/

26. Delong C., Sharma S. Physiology, Peripheral Vascular Resistance. Copyright, StatPearls Publishing LLC. 2019. URI: https://europepmc.org/article/nbk/nbk538308\#free-full-text

27. Elias S.O., Ajayi R.E. Effect of sympathetic autonomic stress from the cold pressor test on left ventricular function in young healthy adults // Physiological Reports. 2019. Vol. 7, Iss. 2. e13985

28. Fossion R., Rivera A.L., Estanol B. A physicist's view of homeostasis: how time series of continuous monitoring reflect the function of physiological variables in regulatory mechanisms // Physiol. Meas. 2018. Vol. 39. URL : https://iopscience.iop.org/article/10.1088/1361-6579/ aad $8 \mathrm{db} / \mathrm{pdf}$

29. Gelber D.A., Pfeifer M., Dawson B. Cardiovascular autonomic nervous system tests: determination of normative values and effect of confounding variables // J. Auton. Nerv. Syst. 1997. Vol. 62. 1,2. P. 40-44.

30. Gordan R., Gwathmey J.K., Lai-Hua Xie. Autonomic and endocrine control of cardiovascular function // World J. Cardiol. 2015. Apr 26; 7(4). P. 204-214.

31. Karemaker J.M. An introduction into autonomic nervous function // Physiol. Measurement. 2017. Vol. 38, № 5. P. 89-118.

32. Magder $S$. The meaning of blood pressure// Magder Critical Care. 2018. Vol. 22. Article 257. URL: https://ccforum.biomedcentral.com/articles/10.1186/s13054-018-2171-1.

33. Mäkinen T.M., Mäntysaari M., Pääkkönen T. and al. Autonomic nervous function during whole-body cold exposure before and after cold acclimation // Aviation, Space, and Environmental Medicine. 2008. Vol. 79, № 9. P. 875-882.

34. Mayet J., Hughes A. Cardiac and vascular pathophysiology in hypertension // Heart. 2003. Vol. 89(9). P. 1104-1109.

35. Monge Garciaa M.I., Gonzalezb H.B. Why did arterial pressure not increase after fluid administration? // Medicina Intensiva. 2017. Vol. 41. № 9. P. 511-578. 
36. Mosteller R.D. Simplified Calculation of Body Surface Area // New England Journal of Medicine. 1987. Vol. 317. N 17. P. 1098.

37. Pichon A., Chapelot D. Homeostatic role of the parasympathetic nervous system in human behavior // Horizons in Neuroscience Research. 2009. Vol. 1 URL: https://www.researchgate. net/publication/260623069_Homeostatic_Role_of_the_Parasympathetic_Nervous_System_ in_Human_Behavior

38. Porges S. $\bar{W}$. Stress and Parasympathetic Control // Encyclopedia of Neuroscience. 2009. Vol. 9. P. $463-469$.

39. Thomas G.D. Neural control of the circulation // Adv Physiol. Educ. 2011. Vol. 35. P. 28-32.

40. Webb W.R., Moulder P.V., Harrison L.H., Broussard M.L. Simple method for evaluating cardiac output // Journal La State Med. Soc. 2009. Vol. 161(5). P. 287-289.

41. Ziemssen T., Siepmann T. The Investigation of the Cardiovascular and Sudomotor Autonomic Nervous System - A Review // Front. Neurol. 2019. Vol. 10. Article 53. URL: https://www. frontiersin.org/articles/10.3389/fneur.2019.00053/full

Стаття надійшла до редакиії 10.12.20

доопрачьована 17.12.20

прийнята до друку 22.12.200

\title{
ОСОБЛИВОСТІ ВЕГЕТАТИВНОГО СТАТУСУ Й АДАПТАЦЙНІ МОЖЛИВОСТІ СТУДЕНТСЬКОЇ МОЛОДІ ЗАЛЕЖНО ВІД ТИПУ САМОРЕГУЛЯЦІї КРОВООБІГУ
}

\author{
В. Задорожня ${ }^{1 *}$, О. Кучковський ${ }^{2}$, О. Ковальова ${ }^{3}$ \\ ${ }^{1}$ Запорізький національний університет \\ вул. Жуковського, 66, Запоріжжя 69600, Україна \\ ${ }^{2} 3$ апорізький державний медичний університет \\ просп. Маяковського, 26, Запоріжжя 69000, Україна \\ ${ }^{3}$ Державна установа \\ «Запорізька медична академія післядипломної освіти МОЗ України» \\ бульв. Вінтера, 20, Запоріжжя 69096, Украӥна \\ e-mail: zadorovic@gmail.com
}

\begin{abstract}
У роботі досліджено особливості вегетативного статусу й адаптаційні можливості дівчат віком від 19 до 21 року залежно від їхнього типу саморегуляції кровообігу. Дослідження проведене на базі біологічного факультету Запорізького національного університету, м. Запоріжжя. У всіх осіб вимірювали первинні показники: частоту серцевих скорочень і артеріальний тиск. На підставі отриманих даних визначали тип саморегуляції кровообігу у кожного обстеженого окремо. На підставі отриманих даних визначали тип саморегуляції кровообігу в кожного обстеженого окремо, що дало змогу сформувати три групи (особи зі серцевим, судинним і змішаним типом саморегуляції кровообігу). До схеми обстеження входив розрахунок таких показників серцево-судинної системи: середньодинамічний тиск, питомий периферичний опір, хвилинний об'єм кровообігу, серцевий індекс, ударний об'єм, зовнішня робота міокарда, індекс напруги міокарда, критерій ефективності міокарда, вегетативний індекс Кердо й адаптаційний потенціал.

Результати проведених експериментів оброблено методами варіаційної статистики, а також проведено кореляційний аналіз отриманих даних.
\end{abstract}


Виявлено певні відхилення щодо референтних значень аналізу середньогрупових параметрів системної гемодинаміки у студенток із різними типами регуляції кровообігу. У осіб зі змішаним і судинним типами регуляції зафіксовано, що середньодинамічний тиск перевищує верхню межу норми на 2,5 та 6,2 \% відповідно. Аналіз отриманих даних щодо показників питомого периферичного опору в дівчат із різними типами саморегуляції кровообігу виявив, що у групах осіб зі змішаним і судинним типами цей показник не перевищував норму, на відміну від групи зі серцевим типом. У останніх питомий периферичний опір був меншим на 5,2 \%, ніж нижня межа референтного значення для цього показника. Виявленно статистично значущі відмінності за показниками хвилинного об'єму кровообігу, серцевого індексу й ударного об'єму в дівчат із різними типами саморегуляції кровообігу. Виявлено певні тенденції середньогрупових та індивідуальних показників роботи міокарда в дівчат залежно від типу саморегуляції. Статистичну достовірність виявлено між показниками індексу напруги міокарда у дівчат із різними типами саморегуляції. У групі осіб зі змішаним типом i середньогрупові, й індивідуальні показники вегетативного індексу Кердо коливалися в межах ейтонії. Середньогрупові значення вегетативного індексу в дівчат зі судинним типом вказували на чітко виражену ваготонію.

Встановлено, що найбільший відсоток усіх обстежених мають задовільну адаптацію. Найбільша кількість дівчат із задовільною адаптацією мали судинний тип саморегуляції $(83,33 \%)$ та змішаний тип $(81,82 \%)$, менший відсоток дівчат із цих груп (16,68 та 18,18 \% відповідно) мали функціональне напруження механізмів адаптації. У групі зі серцевим типом майже половина $(46,15 \%)$ осіб мали функціональне напруження адаптаційних механізмів, а решта $(53,85 \%)$ - задовільну адаптацію.

Таким чином, встановлені відмінності в показниках серцево-судинної системи, співвідношенні впливів на серцево-судинну систему симпатичної і парасимпатичної ланок вегетативної нервової системи, а також адаптаційного потенціалу в дівчат 19-21 року можна віднести до компенсаторно-пристосувальних реакцій організму, зумовлених різними типами саморегуляції кровообігу.

Ключові слова: адаптація, гемо- та кардіодинаміка, вегетативний індекс, показники роботи міокарда, кореляція 